\title{
The Institute for the Study of Man in Africa
}

THE Institute's seventh annual Raymond Dart Lecture, entitled 'Language in Africa', was delivered by Professor Desmond T. Cole, Professor of African Languages in the University of the Witwatersrand, on 2 December $197^{\circ}$.

\section{University of Malawi: Lake Chilwa Co-ordinated Research Project}

THE 1966-1970 Research Report of this project, Decline and Recovery of a Lake, is edited by Professor Margaret Kalk, Director of the Project. The work was carried out under the auspices of the University of Malawi, the objectives being to study the biology and changing morphology of the Lake, to assist in a general ecological study of the north-west area of the Chilwa Plain, with a view to biological control of the red locust, and to improved land use, and to measure the radioactivity in certain soils on Chisi Island and its biological effects. A demographic study of the people of the area was made by Professor Swanzie Agnew. The three districts that cover the lake basin are predominantly Yao, Chewa, and Lomwe speaking and there are a large number of foreign-born settlers from Portuguese territory. The I966 Malawi Population Census showed 300,000 lacustrine people settled in villages under their own headmen. This coincided with the lake being in full production but by 1968 all fishing had ceased, following the drying-up of the lake. Periodic fluctuations in lake level make the fishing industry uncertain and the future development of the area may rest primarily on the agricultural potential of the lacustrine plain. The present recovery of the fishing industry and the adaptive responses of the people in the environs have indirectly contributed to the fish-farming proposals in the irrigation schemes for rice and sugar in the Lower Shire Valley and it is expected that the University of Malawi will be called upon to undertake further researches into the changing environments and new patterns of work.

\section{The Chinese Association of African Studies (see also, Africa, xl. 3, 1970, p. 275)}

THE formation of the Chinese Association of African Studies reflects the growing interest in Africa to be found in the Republic of China (Taiwan). The membership at the initial meeting included professors, diplomats, businessmen, returned technicians, students, and others with a general interest in Africa and African affairs. Among the speakers were Mr. Yang Hsi-kuan, the Vice-Minister of Foreign Affairs, and Dr. Tu Twang-hsun, Director of the Program of African Studies at the National Chengchi University. The membership was established and officers nominated at this first meeting. At present three members of the Board of Directors are former Ambassadors to African countries. Publications of an interdisciplinary nature are to be encouraged and projects will be undertaken which will enhance mutual understanding between the republic of China and the countries of Africa. Additional information may be obtained from: The Chinese Association of African Studies, P.O. Box I-9, Mucha, Tapei, Taiwan I6.

\section{The Language Association of Eastern Africa (LAEA)}

LAEA was founded by members of the Language Study Group of Ethiopia, the Kenya Language Association, the Language Association of Tanzania, the Uganda Language Society, and the Zambia Language Group in co-operation with the Survey of Language Use and Language Teaching sponsored by the Ford Foundation (see Africa, xxxix. 3, 1969, pp. 298-9). The Executive Secretary is Mr. Derek Elderkin, University College, Nairobi.

The aim of the association is to further the scientific and professional study of language in all its aspects, to sponsor conferences, workshops, and seminars and to produce a journal 
addressed to the interests and needs of its members. A conference on 'Language for Development in Eastern Africa' was held in Nairobi from 30 May to 2 June 1970. The first issue of the Journal of the Language Association of East Africa (1970), edited by Tom Gorman and published by the East African Publishing House, Nairobi, contains a Foreword on the Language Association of Eastern Africa and articles, abstracts, book reviews, and notes and news.

\section{Abe Bailey Institute of Inter-Racial Studies at the University of Cape Town}

THE Abe Bailey Institute of Inter-Racial Studies was established in 1968 and is financed by the Abe Bailey Trust. It works in close co-operation with the University of Cape Town although not a formal part of it. The primary purpose of the Institute is to promote and conduct research into inter-group relations in South Africa, especially into relations between race and language groups. It will also be concerned with educational work and will co-operate with existing organizations within and outside the University in the arrangement of lectures and discussions in order to promote a better understanding of inter-group relations. The Director is Professor Hendrik W. van der Merwe and the programme is under the supervision of an academic advisory committee.

The research programme of the Institute includes a study of white South African élites, financed by the Human Sciences Research Council, and originally started under the auspices of the Institute for Social and Economic Research at Rhodes University in 1966. The report on this project is being prepared by the Director, Mrs. N. C. J. Charton and Mr. M. J. Ashley. Dr. R. E. van der Ross has received financial assistance from the Institute towards his study of the political-cultural development of the coloured people during the twentieth century as related to problems of group identity. A series of research seminars has been held and it is hoped to arrange research workshops of 4-6 people to promote discussion between Afrikaans- and English-speaking academics on inter-group relations in South Africa. The future role of the Institute is seen as not only to conduct its own research projects but also to encourage and co-ordinate research between the University of Cape Town and other universities.

\section{Université Mohammed V: Centre Universitaire de la Recherche Scientifique, Rabat (Maroc)}

THE Centre has issued a Bulletin Signalétique listing some 350 papers and other written studies, including twenty-five doctoral theses, presented during the period 1957-69. The text is in French and in Arabic. The first number of the Bulletin de la Societé d'Histoire du Maroc (in French and Arabic) has also recently appeared. Published under the auspices of the Centre Universitaire de la Recherche Scientifique, it may be ordered from the Société des Sciences de l'Homme, Avenue Moulay Cherif, B.P. I054, Rabat; price 8 dirhams (Maroc), 9 dirhams (étranger).

\section{'The Conch'}

The Conch, a bilingual (English and French) sociological journal of African cultures and literatures, was founded in 1967 in memory of the poet Christopher Okigbo. Its field of interest includes all forms of oral and written communication (traditional folklore, myths, legends, and music), factors of social change including modern mass media, poetry, and the novel in Africa. It is edited from the English Department of the University of Texas, Austin, by Dr. S. O. Anonzie. Vol. ii, no. 2 (September 1970) is devoted to 'Structuralism 